\title{
A marketing perspective on business models
}

\author{
Hubert Gatignon ${ }^{1} \cdot$ Xavier Lecocq $^{2} \cdot$ Koen Pauwels $^{3} \cdot$ Alina Sorescu $^{4}$
}

Received: 5 December 2017 / Accepted: 15 December 2017 / Published online: 5 January 2018

(C) Academy of Marketing Science 2018

The Internet and the digital economy have prompted the creation of new business models (McKinsey and Company 2017). Technologies that can enable new business platforms and increased digital access to potential customers have significantly changed in the manner in which firms conduct business, from the creation of value (see, for instance, the literature on co-creation, e.g., Hoyer et al. 2010, or that on open innovation, e.g., Chesbrough et al. 2006), to the appropriation of value (see, for instance, research on freemium pricing, e.g., Pauwels and Weiss 2008, or on pay-per-use, e.g., Prasad et al. 2003). Competitive advantage from product innovation has become difficult to maintain for extended periods of time; as a result, incumbents are increasingly looking for ways to update and innovate their existing business models (Neus et al. 2017). For instance, Accenture reports that $80 \%$ of firms plan to grow via new business models over the next 5 years (Accenture 2014).

Changes in business practice have also led to a heightened focus on business models in the academic literature. Several

Hubert Gatignon

hubert.gatignon@insead.edu

Xavier Lecocq

xavier.lecocq@univ-lille1.fr

Koen Pauwels

kpauwels@northeastern.edu

Alina Sorescu

asorescu@tamu.edu

1 INSEAD, Boulevard de Contance, 77305 Fontainebleau Cedex, France

2 IESEG School of Management, IAE Lille, 104 Avenue du Peuple Belge, 59043 Lille Cedex, France

3 BI Norwegian Business School, D'Amore-McKim School of Business, Northeastern University, 205E Hayden Hall, 360 Huntington Avenue, Boston, MA 02118, USA

4 Texas A\&M University, 4112 TAMU, College Station, TX 77843-4112, USA recent reviews highlight the scope of this literature, which ranges from attempts to define and provide structure for the concept of business model, to examinations of specific types of business models (Coombes and Nicholson 2013; Foss and Saebi 2017; Massa et al. 2017; Zott et al. 2011). The majority of these articles, however, can be found in management journals. Attempts to study business models in marketing are scant, and typically focus on specific sectors of the economy (e.g., Wieland et al. 2017 on services, and Sorescu et al. 2011 on retailing) or on specific types of business models (e.g., Kind et al. 2009; Pauwels and Weiss 2008). Moreover, while value creation and appropriation have separately received attention in marketing, they have been rarely studied in combination, which is a prerequisite to understanding business models. This is a surprising gap, given that marketers are responsible for the design and implementation of several aspects of the value creation and value appropriation components of a business model. This special issue is a first step in stimulating more research on this topic in the marketing literature. Building on what we have learned from the management literature but bringing insights from the marketing literature's expertise on building a viable value proposition, we can further enhance our understanding of how business models can be effectively designed in order to lead to sustainable firm performance.

\section{Value creation, value appropriation and the value proposition}

From the early 2000's, researchers in management, strategy and entrepreneurship have endeavored to conceptualize the notion of business model. Several tools to describe the components of a business model have been developed, such as the Canvas (Osterwalder and Pigneur 2013) or the RCOV framework (Demil and Lecocq 2010). Moreover, the notion of business model has been contrasted with the traditional concept of strategy, with Casadesus-Masanell and Ricart (2010) calling the business model a reflection of a firm's realized strategy. 
Business models have also been credited with prompting a renewed view of strategic thinking (Lecocq et al. 2010).

The marketing discipline is underrepresented in the strong stream of over a thousand scholarly articles focused on business models (Coombes and Nicholson 2013; Zott et al. 2011). However, a closer look at this research stream reveals that many authors emphasize that the purpose of the business model is to articulate a firm's value proposition and to propose a "viable structure of revenues and costs for the enterprise delivering that value" (Teece 2010, p.178). The value proposition-which explains how the products and services offered by the firm match the needs of the targeted market segmentis a core marketing concept (Frow and Payne 2011; Skålén et al. 2015). Thus, marketing academics should be favorably positioned to contribute to this important literature.

Why has marketing literature yet to contribute substantively to the development of knowledge on business models? We believe a key reason is the separate attention given in marketing to either value creation (mostly in the form of product innovation) or value appropriation (mostly in the form of pricing and 'marketing mix' instruments). Understanding business models requires studying both processes simultaneously, as well as their interactions; as this is a complex endeavor, most attempts to integrate them remain at the conceptual level (e.g. Brandenburger and Stuart 1996; Bowman and Ambrosini 2000). A notable exception is Sorescu et al. (2011), who propose concrete practices in retail industry associated with value creation and value capture.

The development of research on business models in marketing could help the field better understand how to design more effective value creation and value appropriation processes for different types of firms. Indeed, the strategic management literature, which used to be largely focused on value appropriation (Demil et al. 2015), has benefited from the development of the business model concept. Bringing this concept into extant literature has led to a better integration of value creation for the customer within the value creation frameworks for the firm and its shareholders (Priem et al. 2012; Tantalo and Priem 2016).

\section{Insights from the special issue}

The papers included in the special issue can be classified into two broad categories. First, several authors bring a marketing perspective to conceptualizing the notion of business model at a general level. Second, several papers focus on how to best address a specific segment with a business model tailored to that segment's needs.

Within the first category, Robertson (2017) proposes an ecosystem of business model innovation (BMI) combining external elements, particularly customer segments and value chains (very much in the domain of marketing), with internal elements, particularly organizational processes (much more in the domains of strategic management and especially organizational behavior). Robertson develops a conceptual model with the objective of answering the question of how a BMI value proposition is derived. The article identifies the factors that are critical in how BMI emerges and how consumers' responses to BMI differ from their reactions to pure product or service innovations. In order to help advance marketing research on BMI, the author proposes a set of research hypotheses related to these factors. In the same vein, Nystrom and Mustonen (2017) go beyond a static perspective to further develop the flexible and adaptive nature of business models based on an industrial network approach. Nystrom and Mustonen (2017) argue that the business model cannot be conceptualized in isolation; rather it is embedded in business contexts and business networks, and as a result it evolves with changes in the business environment. Leischnig et al. (2017) also highlight the flexible nature of successful business models. These authors conceptualize business models as a configuration of interdependent components influencing how the firm can achieve its strategic objectives. The authors draw on configuration theory to discuss how marketing may benefit from such a view and how the discipline may contribute to configurational thinking.

Finally, a unique perspective on how incumbents can update their business models as they compete with more flexible startups is provided by Seggie et al. (2017). They provide an integrated process for corporate innovation learning through combining the lean startup methodology with big data. By themselves, the volume, variety and velocity of big data may trigger confirmation bias, communication problems and illusions of control. However, if firms also adapt elements from the lean startup methodology, then they can innovate their business models to build competitive advantage in a similar manner to how startups achieve this advantage. Specifically, incumbents could update their business models through fast verification of managerial hypotheses, innovation accounting and the build-measure-learn-loop cycle. Such advice is especially valid for environments with high levels of technological and demand uncertainty.

The second category of articles included in the special issue is a reflection of the fact that conceptualizing business models is a useful theoretical exercise but may present challenges to academics and practitioners interested in specific types of business models that can be designed to help capture a particular customer segment that has unique needs. Several papers in the special issue address this topic. For instance, Prabhu et al. (2017) focus on poor consumers in emerging markets. Marketing to this segment presents multiple challenges: such consumers may not be aware of the product or service, may not be able to gain access to it or to afford it. Drawing on institutional theory, the authors present a model of exchange in emerging markets where the seller takes an 
entrepreneurial role and spearheads a process of institutional change that eventually mitigates these challenges and makes the exchange possible. While the process of institutional change is presented in general terms, specific business model applications are presented in the paper. The various types of business models discussed in this article illustrate the complexity of the ecosystem of value creation in emerging markets, which includes sellers having to go beyond the boundaries of their firms and having to change the environment in order to enable their business model to fulfill its role.

A different perspective on how to use the business model to strengthen the value proposition is provided by Tower and Noble (2017), who focus on collective open business models. This type of business model draws from the notion of interdependent consumer collectives, which are groups of consumers who benefit from resource complementarities in the pursuit of achieving a superior consumption experience, such as communities who play videogames online. Tower and Noble (2017) propose a set of propositions that link actions taken inside interdependent consumer collectives to notions of collective value creation, delivery and capture. In doing so, they delineate the characteristics of the collective open business model and help firms who serve consumer collectives better understand and leverage the characteristics of their segments. Finally, Fedorenko and Berthon (2017) recognize that consumers are not only static recipients at the end of the value creation chain, but rather potential participants in the process of co-creation. Moreover, the authors go beyond traditional wisdom, and show that in crowdsourcing business models contributors are usually a special kind of non-consumer multi-role stakeholder. They discuss how these contributors are creating value and what types of rewards they are seeking.

Altogether, the articles of this special issue are demonstrating the potential of marketing to contribute to knowledge about business models through a better integration of value creation and value appropriation processes and through linking the behavior of various firm stakeholders to the components of the business model.

\section{This is just the start: An agenda for future marketing research on business models}

Despite the richness of business model literature in strategic management, much remains to be studied in this domain, particularly from a marketing perspective (Massa et al. 2017; Wirtz et al. 2016). The special issue starts the scholarly conversation on how marketing knowledge can refine the general conceptualization of business models and help design effective business models for specific segments. However, many research questions are still unanswered. We list a few below, in hopes that the marketing field will continue to focus on this important topic.
First, more attention should be dedicated to the antecedents of BMI. Prior research acknowledges that a primary role of the business model is to define new ways to operate within a sector, going beyond business as usual (Arend 2013). Robertson (2017) tackles this central issue. However, we still lack a clear understanding of how firms can innovate their existing business models. Innovation in business models can be studied from two perspectives. First, BMI can arise as a result to changes in the business environment, such as the availability of new technologies, the increased digitization of business processes, the availability of big data and the advent of artificial intelligence. Seggie et al. (2017) and Sorescu (2017) provide examples of how big data can be leveraged to innovate business models; however, to our knowledge, no research has yet explored how artificial intelligence will change the way in which firms conduct business, despite its significant potential to change the value creation and appropriation processes that firms currently use. Second, BMI can arise in response to serving a specific segment. In this special issue, Prabhu et al. (2017) focus on poor consumers in emerging markets and Tower and Noble (2017) examine interdependent consumer collectives. Many other segments are in need of business models that require significant adaptations from the general conceptualization. Third, BMI may become necessary for incumbents faced with tectonic shifts in their industries, such as the private transportation and hotel industries facing new business models brought about by the gig economy (e.g., Uber and Airbnb). Seggie et al. (2017) provide one avenue that incumbents can use to innovate their business models but this stream remains one that is in significant need of further research.

A second important issue that marketers can address is the role of customers in helping design business models. Literature on crowdsourcing and open innovation is growing and one of the papers included in the special issue, Fedorenko and Berthon (2017), provide novel insights in the dynamics of crowdsourced business models. Additional questions that still require an answer involve the extent to which crowdsourcing should be incorporated in a business model so that firms would retain sufficient control over their message and the equity of their brands. Should firms involve both customers and non-customers in the value creation aspect of the business model? Does crowdsourcing result in products that have a competitive advantage or is it likely to encourage incremental innovation? Does crowdsourcing have an effect on customer acquisition and retention? And how can it be streamlined so that effective ideas from outside stakeholders can be more easily identified and more quickly incorporated into various elements of the business model? These are just a few of the questions that future research could address.

Third, marketing has a long tradition of studying competition and its impact on value creation and appropriation processes. Promising questions in this domain include: How does 
the diffusion of business models through an industry differ from the diffusion of products? Are there network effects in business model diffusion? What is the consequence of business model diffusion on competition? Can BMI provide a longer lasting competitive advantage than product innovation? Nystrom and Mustonen (2017) provide a starting point by arguing that competitive advantage can be created not only from unique business model features, but also from firms' ability to continuously update their business models in response to changes in their environment. Future research should propose specific ways in which business models can be designed so that changes can be made quickly and with low operational and human resource costs.

We hope that the papers included in this special issue provide an impetus for other authors to work on the important topics of business models, business model innovation, and the impact of business models on customer outcomes, firm performance and industry dynamics.

\section{References}

Accenture. (2014). Remaking customer markets: Unlocking growth with digital, Accenture Report.

Arend, R. J. (2013). The business model: Present and future-Beyond a skeumorph. Strategic Organization, 11(4), 390-402. https://doi.org/ $10.1177 / 1476127013499636$.

Bowman, C., \& Ambrosini, V. (2000). Value creation versus value capture: Towards a coherent definition of value in strategy. British Journal of Management, 11(1), 1-15. https://doi.org/10.1111/ 1467-8551.00147.

Brandenburger, A. M., \& Stuart, H. W. (1996). Value-based business strategy. Journal of Economics \& Management Strategy, 5(1), 5-24.

Casadesus-Masanell, R., \& Ricart, J. E. (2010). From strategy to business models and onto tactics. Long Range Planning, 43(2), 195-215. https://doi.org/10.1016/j.lrp.2010.01.004.

Chesbrough, H., Vanhaverbeke, W., \& West, J. (Eds.). (2006). Open innovation: Researching a new paradigm. Oxford: Oxford University Press on Demand.

Coombes, P. H., \& Nicholson, J. D. (2013). Business models and their relationship with marketing: A systematic literature review. Industrial Marketing Management, 42(5), 656-664. https://doi. org/10.1016/j.indmarman.2013.05.005.

Demil, B., \& Lecocq, X. (2010). Business model evolution: In search of dynamic consistency. Long Range Planning, 43(2), 227-246. https://doi.org/10.1016/j.lrp.2010.02.004.

Demil, B., Lecocq, X., Ricart, J. E., \& Zott, C. (2015). Introduction to the SEJ special issue on business models: Business models within the domain of strategic entrepreneurship. Strategic Entrepreneurship Journal, 9(1), 1-11. https://doi.org/10.1002/sej.1194.

Fedorenko, I., \& Berthon, P. (2017). Beyond the expected benefits: unpacking value co-creation in crowdsourcing business models. AMS Review, 7(3-4). https://doi.org/10.1007/s13162-017-0106-7.

Foss, N. J., \& Saebi, T. (2017). Fifteen years of research on business model innovation: How far have we come, and where should we go? Journal of Management, 43(1), 200-227. https://doi.org/10. 1177/0149206316675927.
Frow, P., \& Payne, A. (2011). A stakeholder perspective of the value proposition concept. European Journal of Marketing, 45(1/2), 223-240. https://doi.org/10.1108/03090561111095676.

Hoyer, W. D., Chandy, R., Dorotic, M., Krafft, M., \& Singh, S. S. (2010). Consumer cocreation in new product development. Journal of Service Research, 13(3), 283-296. https://doi.org/10.1177/ 1094670510375604.

Kind, H. J., Nilssen, T., \& Sørgard, L. (2009). Business models for media firms: Does competition matter for how they raise revenue? Marketing Science, 28(6), 1112-1128. https://doi.org/10.1287/ mksc.1090.0514.

Lecocq, X., Demil, B., \& Ventura, J. (2010). Business models as a research program in strategic management: An appraisal based on Lakatos.M@n@gement, 13(4),214-225.https://doi.org/10.3917/ mana.134.0214.

Leischnig, A., Ivens, B. S., \& Kammerlander, N. (2017). A new conceptual lens for marketing: A configurational perspective based on the business model concept. AMS Review, 7(3-4). https://doi.org/10. 1007/s13162-017-0107-6.

Massa, L., Tucci, C., \& Afuah, A. (2017). A critical assessment of business model research. Academy of Management Annals, 11(1), 73104. https://doi.org/10.5465/annals.2014.0072.

McKinsey \& Company. (2017). Setting an agenda for organic growth in the digital age. [podcast]. Bengaluru: Digital McKinsey.

Neus, A., Buder, F., \& Galdino, F. (2017). Are you too successful to digitalize? How to fight innovation blindness. GfK Marketing Intelligence Review, 9(1), 30-35.

Nystrom, A. G., \& Mustonen, M. (2017). The dynamic approach to business models. AMS Review, 7(3-4). https://doi.org/10.1007/ s13162-017-0103-x.

Osterwalder, A. and Pigneur, Y., (2013). Business model generation: A handbook for visionaries, game changers, and challengers. Hoboken: Wiley.

Pauwels, K., \& Weiss, A. (2008). Moving from free to fee: How online firms market to change their business model successfully. Journal of Marketing, 72(3), 14-31. https://doi.org/10.1509/jmkg.72.3.14.

Prabhu, J., Tracey, P., \& Hassan, M. (2017). Marketing to the poor: An institutional model of exchange in emerging markets. AMS Review, 7(3-4). https://doi.org/10.1007/s13162-017-0100-0.

Prasad, A., Mahajan, V., \& Bronnenberg, B. (2003). Advertising versus pay-per-view in electronic media. International Journal of Research in Marketing, 20(1), 13-30. https://doi.org/10.1016/S01678116(02)00119-2.

Priem, R. L., Li, S., \& Carr, J. C. (2012). Insights and new directions from demand-side approaches to technology innovation, entrepreneurship, and strategic management research. Journal of Management, 38(1), 346-374. https://doi.org/10.1177/0149206311429614.

Ranjan, K. R., \& Read, S. (2016). Value co-creation: Concept and measurement. Journal of the Academy of Marketing Science, 44(3), 290-315. https://doi.org/10.1007/s11747-014-0397-2.

Robertson, T. S. (2017). Business model innovation: A marketing ecosystem view. AMS Review, 7(3-4). https://doi.org/10.1007/s13162017-0101-z.

Seggie, S., Soyer, E. \& Pauwels K. (2017). Combining big data and lean startup methods for business model evolution. AMS Review, 7(3-4). https://doi.org/10.1007/s13162-017-0104-9.

Skålén, P., Gummerus, J., von Koskull, C., \& Magnusson, P. (2015). Exploring value propositions and service innovation: A servicedominant logic study. Journal of the Academy of Marketing Science, 43(2), 137-158.

Sorescu, A. (2017). Data-Driven Business Model Innovation. Journal of Product Innovation Management, 34(5), 691-696. https://doi.org/ 10.1111/jpim.12398.

Sorescu, A., Frambach, R. T., Singh, J., Rangaswamy, A., \& Bridges, C. (2011). Innovations in retail business models. Journal of Retailing, 87(Supplement 1), S3-S16. 
Tantalo, C., \& Priem, R. L. (2016). Value creation through stakeholder synergy. Strategic Management Journal, 37(2), 314-329. https:// doi.org/10.1002/smj.2337.

Teece, D. J. (2010). Business models, business strategy and innovation. Long Range Planning, 43(2), 172-194. https://doi.org/10.1016/j.lrp. 2009.07.003.

Tower, A., \& Noble, C. (2017). Exploring and extending a collective open business model. AMS Review, 7(3-4). https://doi.org/10.1007/ s13162-017-0105-8.
Wieland, H., Hartmann, N. N., \& Vargo, S. L. (2017). Business models as service strategy. Journal of the Academy of Marketing Science, 45(6), 925-943. https://doi.org/10.1007/s11747-017-0531-z.

Wirtz, B., Pistoia, A., Ullrich, S., \& Göttel, V. (2016). Business models: Origin, development and future research perspectives. Long Range Planning, 49(1), 36-54. https://doi.org/10.1016/j.lrp.2015.04.001.

Zott, C., Amit, R., \& Massa, L. (2011). The business model: Recent developments and future research. Journal of Management, 37(4), 1019-1042. https://doi.org/10.1177/0149206311406265. 